\title{
PENGARUH KONSENTRASI LARUTAN DAUN JAMBU BIJI (Psidium guajava) DAN LAMA PERENDAMAN TERHADAP KUALITAS TELUR AYAM RAS
}

\author{
Tri Ernawati, Linda Ch. M. Karisoh*, Rahmawaty Hadju, Surtijono E. Siswosubroto
}

Fakultas Peternakan Universitas Sam Ratulangi Manado, 95115

\begin{abstract}
ABSTRAK
Penelitian ini bertujuan untuk mengetahui sampai sejauh mana pengaruh konsentrasi larutan daun jambu biji dan lama perendaman terhadap kualitas telur ayam ras. Metode yang digunakan adalah Rancangan Acak Lengkap (RAL) dengan pola faktorial yang terdiri dari 2 faktor. Faktor A yaitu konsentrasi larutan daun jambu biji dan faktor B adalah lama perendaman dengan 4 ulangan. Perlakuan yang digunakan yaitu : Faktor A konsentrasi larutan daun jambu biji $\mathrm{A} 1=3 \%$, $\mathrm{A} 2=6 \%, \mathrm{~A} 3=9 \%, \mathrm{~A} 4=12 \%$. Faktor B lama perendaman $\mathrm{B} 1=6 \mathrm{jam}, \mathrm{B} 2=12 \mathrm{jam}, \mathrm{B} 3=18$ jam, B4 $=24$ jam. Variabel yang dianalisis pada penelitian ini adalah penurunan berat telur, indeks putih telur, indeks kuning telur. Data yang diperoleh dianilisis ragam. Apabila terdapat perbedaan yang nyata antara perlakuan akan dilanjutkan dengan Uji Duncan. Hasil analisis ragam menunjukkan bahwa interaksi berpengaruh nyata $(\mathrm{P}<0,05)$ terhadap penurunan berat telur dan tidak berpengaruh nyata $(\mathrm{P}>0,05)$ terhadap indeks putih telur dan indeks kuning telur. Hasil Uji Duncan untuk penurunan berat telur menunjukkan konsentrasi larutan daun jambu biji 3\% dan lama perendaman 6 jam memberikan hasil yang baik bagi kualitas telur ayam ras. Kesimpulan dari hasil penelitian ini adalah Konsentrasi 3\% dan lama perendaman 6 jam memberikan hasil yang baik pada penurunan berat telur. Sementara untuk indeks putih telur dan indeks kuning telur menunjukkan hasil yang baik dengan konsentrasi $12 \%$ dan lama perendaman 24 jam.
\end{abstract}

Kata Kunci : Daun Jambu Biji, Penurunan Berat Telur, Indeks Putih Telur, Indeks Kuning Telur

*Kosepondensi (corresponding author)

Email : linda_karisoh@yahoo.com

\section{ABSTRACT}

$\begin{array}{lrr}\text { THE EFFECT OF GUAVA } & \text { LEAF } \\ \text { SOLUTION CONCENTRATION } & \text { AND } \\ \text { SOAKING DURATION ON } & \text { THE } \\ \text { QUALITY OF CHICKEN EGGS. } & \text { This }\end{array}$

study aims to determine the effect of guava leaf solution concentration and soaking time on the quality of chicken eggs. This research was conducted from November to December 2018, at the Laboratory of Animal Product Technology, Faculty of Animal Husbandry, Sam Ratulangi University, Manado. The method used is Completely Randomized Design (CRD) with a factorial pattern consisting of 2 factors. Factor A was the concentration of solution of guava leaves and factor $\mathrm{B}$ is the length of immersion with 4 replications. The treatments used are: Factor $\mathrm{A}$ concentration of solution of guava leaves $\mathrm{A} 1=$ $3 \%, \mathrm{~A} 2=6 \%, \mathrm{~A} 3=9 \%, \mathrm{~A} 4=12 \%$. Factor $\mathrm{B}$ was duration of immersion $\mathrm{B} 1=6$ hours, $\mathrm{B} 2=$ 12 hours, B3 $=18$ hours, $\mathrm{B} 4=24$ hours. The variables analyzed were a decrease in egg weight, egg white index and egg yolk index. Data obtained were analyzed by variety. If there are significant differences between treatments, it will be continued with Duncan Test. The results of the variance analysis showed that the interaction had a significant effect $(\mathrm{P}<0.05)$ on the decrease in egg weight and did not significantly influence $(\mathrm{P}>0.05)$ on the egg white index and egg yolk index. Duncan's Test results for decreasing egg weight showed the concentration of guava leaf solution $3 \%$ and soaking time 6 hours gave good results for the quality of chicken eggs. It was concluded that the concentration of 3\% and the soaking time of 6 hours gives good results on decreasing egg weight. As for the egg white index and egg yolk index showed good results with concentration of $12 \%$ and 24-hour immersion time.

Keywords: Guava leaf, Egg weight, Egg white index, Egg yolk index. 


\section{PENDAHULUAN}

Telur merupakan salah satu sumber protein hewani disamping daging, ikan dan susu, yang sangat baik dikonsumsi oleh manusia baik anak-anak pada masa pertumbuhan, ibu hamil, dan menyusui, serta mereka yang sedang dalam proses penyembuhan setelah sakit. Secara umum telur akan mengalami kerusakan setelah disimpan lebih dari dua minggu di ruang terbuka. Kerusakan awal berupa pecah, dan retak, diikuti kerusakan lain akibat udara dalam isi telur yang keluar sehingga derajat keasaman naik. Keluarnya uap air dari dalam telur membuat berat telur turun serta putih telur encer mengakibatkan kesegaran telur menurun. Kerusakan telur juga terjadi akibat penunurunan kualitas telur antara lain dibiarkan atau disimpan diudara terbuka melebihi waktu kesegaran, pernah jatuh atau terbentur benda kasar sehingga menyebabkan cangkang telur retak, dan keluarnya gas karbondioksida pada telur. Untuk mengatasi terjadinya kerusakan maka perlu diadakan pengawetan agar nilai gizinya tetap tinggi, tidak berubah rasa, tidak berbau busuk dan warna isinya tidak pudar. Pengawetan dapat dilakukan dengan cara kering, pengawetan basah, perendaman, penutupan kulit dengan bahan pengawet dan penyimpan dalam ruangan pendingin.
Teknik pengawetan dengan perendaman dalam larutan pengawet daun jambu biji yang mengandung tanin telah banyak dilakukan. Daun jambu biji (Psidium guajava) merupakan daun tunggal yang berbentuk bulat telur, ujungnya tumpul, pangkal membulat dan tepinya rata. Kandungan kimia daun jambu biji berupa tanin dapat mengawetkan telur ayam ras. (Fadlillah et al., 2010). Pada daun jambu biji (Psidium guajava) terdapat senyawa tanin antara 3,25-8,98\%. Tanin yang bersifat menyamak kulit telur dapat memperpanjang umur simpan telur. Tanin akan menyebabkan protein dipermukaan kulit telur menggumpal dan menutupi poripori, mencegah terjadinya penguapan, mencegah hilangnya $\mathrm{CO}^{2}$, dan mencegah masuknya mikroorganisme sehingga telur menjadi lebih awet (Kamilah et al., 2010).

Berdasarkan latar belakang maka telah dilakukan suatu penelitian tentang penggunaan larutan daun jambu biji dan lama perendaman terhadap kualitas telur ayam ras.

\section{MATERI DAN METODE PENELITIAN}

Bahan yang digunakan dalam penelitian ini adalah telur ayam ras berumur 1 hari sebanyak 256 butir, dengan rataan berat 55 sampai 60 gram. Telur yang diseleksi berwarna coklat bersih, tidak retak 
tekstur kerabang halus, bentuk oval. daun jambu biji, Bahan lain yang digunakan adalah aquadestilata. Alat yang digunakan pada penelitian ini adalah timbangan digital, jangka sorong,

Penelitian ini menggunakan rancangan acak lengkap (RAL) dengan pola faktorial yang terdiri dari 2 faktor. Faktor A yaitu konsentrasi larutan daun jambu biji dan faktor $B$ adalah lama perendaman dengan 4 ulangan (Kusriningrum, 2010). Pengaturannya dilakukan sebagai berikut :

Faktor A adalah konsentrasi larutan daun jambu biji yang akan digunakan:

$$
\begin{aligned}
& \mathrm{A} 1=3 \% \\
& \mathrm{~A} 2=6 \% \\
& \mathrm{~A} 3=9 \% \\
& \mathrm{~A} 4=12
\end{aligned}
$$

Faktor B adalah lama perendaman :

$$
\begin{aligned}
& \mathrm{B} 1=6 \mathrm{jam} \\
& \mathrm{B} 2=12 \mathrm{jam} \\
& \mathrm{B} 3=18 \mathrm{jam} \\
& \mathrm{B} 4=24 \mathrm{jam}
\end{aligned}
$$

Data dianalisa menggunakan analisis keragaman dan perbedaan antar perlakuan diuji dengan Duncun multiple range test (DMRT).

Pembuatan Larutan Daun Jambu Biji :
Daun jambu biji berwarna hijau tua

Dicacah atau potong kecil-kecil Ditimbang 3gr, 6gr, 9gr, 12 gr

Ditambahkan air 1 liter dan dituangkan kedalam panci

Direbus sampai mendidih selama 10 menit

Disaring untuk menghilangkan ampasnya

$$
\text { larutan daun jambu biji }
$$

Gambar 1. Diagram Alir Pembuatan Larutan Jambu Biji.

Prosedur Penelitian :

Telur ayam ras segar, dibersihkan dengan menggunakan kain yang dibasahi dengan air hangat, setelah itu diletakkan di egg tray dan ditimbang berat awal telur. Selanjutnya telur dimasukkan kedalam kantong plastik klip kemudian diletakkan ke dalam wadah plastik lalu ditambahkan larutan daun jambu biji sesuai dengan perlakuan 3\%, $6 \%, 9 \%, 12 \%$. Selanjutnya direndam selama 6 jam, 12 jam, 18 jam, 24 jam. Setelah perendaman telur diangkat dari perendaman larutan daun jambu biji dan diletakkan di egg tray lalu disimpan selama 30 hari selanjutnya di analisa.

Variabel yang diamati dalam penelitian ini adalah : 


\section{Penurunan Berat Telur}

Penurunan berat telur di hitung dengan cara menimbang berat awal telur (gram), dikurangi dengan berat akhir telur (gram) setelah disimpan, dibagi dengan berat awal telur (gram), dan kemudian dikali 100\% (Hintono, 1997).

Dihitung menggunakan rumus:

$\frac{\text { Berat Awal }(\mathrm{gram})-\text { Berat Akhir }(\mathrm{gram})}{\text { Berat Awal }(\mathrm{gram})} \times 100 \%$

\section{Indeks Putih Telur}

Indeks putih telur ditentukan dengan mengukur tinggi dan diameter putih telur dengan jangka sorong.

Indeks Putih Telur

$$
=\frac{\text { Tinggi Putih Telur }(\mathrm{mm})}{\text { Diameter Putih telur }(\mathrm{mm})}
$$

\section{Indeks Kuning Telur}

Indeks kuning telur ditentukan dengan mengukur tinggi dan diameter kuning telur dengan jangka sorong.
Indeks Kuning Telur

$$
=\frac{\text { Tinggi Kuning Telur }(\mathrm{mm})}{\text { Diameter Kuning Telur }(\mathrm{mm})}
$$

\section{HASIL DAN PEMBAHASAN}

\section{Penurunan Berat Telur}

Penurunan berat telur dengan perlakuan konsentrasi larutan daun jambu biji dan lama perendaman dapat dilihat pada Tabel 1.

Rataan nilai penurunan berat telur (Tabel 1) berkisar antara 6,143-7,663 gram. Hasil penelitian ini masih lebih tinggi dibandingkan dengan hasil penelitian dari Riawan et al. (2017) adalah sebesar 5,38 5,62 gram yang menggunakan larutan daun kelor terhadap lama penyimpanan telur. Hasil analisis ragam menunjukkan bahwa interaksi antara faktor A (konsentrasi larutan) dan faktor B (lama perendaman) berpengaruh nyata $(\mathrm{P}<0,05)$ terhadap penurunan berat

\begin{tabular}{|c|c|c|c|c|c|}
\hline \multirow{2}{*}{$\begin{array}{c}\text { Konsentrasi } \\
\text { Larutan } \\
\text { Daun Jambu } \\
\text { Biji }(\%)\end{array}$} & \multicolumn{4}{|c|}{ Lama Perendaman (Jam) } & \multirow{2}{*}{$\begin{array}{l}\text { Rataan } \\
\text { (gram) }\end{array}$} \\
\hline & 6 & 12 & 18 & 24 & \\
\hline 3 & $1,852 \pm 0,401$ & $4,990 \pm 1,344$ & $5,187 \pm 0,590$ & $5,995 \pm 1,387$ & $4,506 \pm 1,871^{\mathrm{a}}$ \\
\hline 6 & $6,710 \pm 1,383$ & $3,465 \pm 0,756$ & $9,762 \pm 0,813$ & $9,977 \pm 2,507$ & $7,478 \pm 3,065^{b}$ \\
\hline 9 & $8,962 \pm 1,084$ & $10,020 \pm 0,558$ & $4,257 \pm 0,454$ & $7,810 \pm 0,930$ & $7,760 \pm 2,356^{\mathrm{b}}$ \\
\hline 12 & $7,047 \pm 1,307$ & $9,902 \pm 0,697$ & $6,070 \pm 0,580$ & $6,870 \pm 1,610$ & $7,472 \pm 1,808^{b}$ \\
\hline Rataan & $6,143 \pm 2,885^{\mathrm{a}}$ & $6,316 \pm 2,230^{\mathrm{ab}}$ & $7,094 \pm 3,116^{\mathrm{bc}}$ & $7,663 \pm 2,163^{c}$ & \\
\hline
\end{tabular}

Tabel 1. Rataan Penurunan Berat Telur

Keterangan : superskrip berbeda pada baris yang sama menunjukan perbedaan yang nyata $(\mathrm{P}<0.05)$; $\mathrm{Sd}=\mathrm{Standar}$ deviasi. 
telur. Berdasarkan nilai rata-rata penurunan berat telur pada konsentrasi 3\% dengan lama perendaman 6 jam menghasilkan nilai penurunan yang lebih kecil dibandingkan dengan perlakuan yang lainnya. Hal ini karena kandungan tanin pada konsentrasi 3\% dengan lama perendaman 6 jam sudah maksimal dalam melapisi kerabang telur untuk menghambat transfer $\mathrm{H}_{2} \mathrm{O}$ dan $\mathrm{CO}_{2}$ melalui pori-pori, dan tidak menyebabkan kontaminasi mikroorganisme sehingga tidak menyebabkan kerusakan pada telur.

Rataan konsentrasi larutan daun jambu biji berpengaruh nyata $(\mathrm{P}<0,05)$ terhadap penurunan berat telur. Hasil uji Duncan menunjukkan bahwa penurunan berat telur dengan konsentrasi larutan daun jambu biji $3 \%$ berbeda nyata lebih rendah dibandingkan dengan $6 \%, 9 \%$ dan $12 \%$, tetapi antara 6\%, 9\% dan 12\% tidak terdapat perbedaan. Hasil ini menunjukkan bahwa semakin tinggi nilai konsentrasi larutan daun jambu biji yang digunakan untuk merendam telur maka nilai penurunanan berat telur semakin tinggi. Hal ini disebabkan kandungan tanin sampai pada konsentrasi $12 \%$ diduga belum maksimal dalam melapisi kerabang telur untuk menghambat terjadinya transfer air dan karbondioksida melalui pori-pori.

Rataan lama perendaman daun jambu biji berpengaruh nyata $(\mathrm{P}<0,05)$ terhadap penurunan berat telur. Hasil uji
Duncan menunjukkan bahwa lama perendaman 6 jam dan 12 jam berbeda nyata lebih rendah dibandingkan perendaman 18 jam dan 24 jam. Hal ini menunjukkan bahwa semakin lama telur direndam maka nilai perendaman pada penurunan berat telur semakin tinggi. Kandungan tanin pada daun jambu biji yang sedikit menyebabkan kontaminasi mikroorganisme masih terjadi sehingga menyebabkan kerusakan pada telur.

Mikroorganisme mendegradasi sebagian senyawa pada telur terutama pada putih telur sehingga menjadi encer dan mempercepat proses penguapan air dan gas $\mathrm{CO}_{2}, \mathrm{NH}_{2}, \mathrm{~N}_{2}$ dan $\mathrm{H}_{2} \mathrm{~S}$. Haryoto (1993) yang disitasi oleh Riawan et al. (2017) menyatakan bahwa telur dapat mengalami kerusakan fisik yang disebabkan oleh bakteri. Dijelaskan lebih lanjut bahwa meningkatnya lama penyimpanan sejalan dengan meningkatnya bakteri dalam telur. Faktor lain yang mempengaruhi kerusakan (penurunan berat telur) yaitu suhu, kelembaban ruang penyimpanan, kotoran pada kulit telur dan teknik penanganan serta peralatan yang digunakan dalam penanganan.

\section{Indeks Putih Telur}

Rataan indeks putih telur (Tabel 2) yang menggunakan konsentrasi larutan daun jambu biji berkisar antara $0,023 \mathrm{~mm}$ 
Tabel 2. Rataan Indeks Putih Telur

\begin{tabular}{|c|c|c|c|c|c|}
\hline \multirow{2}{*}{$\begin{array}{c}\text { Konsentrasi } \\
\text { Larutan Daun } \\
\text { Jambu Biji (\%) }\end{array}$} & \multicolumn{4}{|c|}{ Lama Perendaman (Jam) } & \multirow{2}{*}{$\begin{array}{l}\text { Rataan } \\
(\mathrm{mm})\end{array}$} \\
\hline & 6 & 12 & 18 & 24 & \\
\hline 3 & $0,015 \pm 0,058$ & $0,017 \pm 0,096$ & $0,030 \pm 0,000$ & $0,030 \pm 0,082$ & $0,023 \pm 0,095$ \\
\hline 6 & $0,022 \pm 0,005$ & $0,025 \pm 0,058$ & $0,050 \pm 0,141$ & $0,025 \pm 0,058$ & $0,031 \pm 0,140$ \\
\hline 9 & $0,025 \pm 0,058$ & $0,027 \pm 0,095$ & $0,030 \pm 0,011$ & $0,032 \pm 0,015$ & $0,038 \pm 0,062$ \\
\hline 12 & $0,025 \pm 0,013$ & $0,042 \pm 0,029$ & $0,032 \pm 0,012$ & $0,037 \pm 0,095$ & $0,032 \pm 0,014$ \\
\hline Rataan & $0,022 \pm 0,083$ & $0,028 \pm 0,142$ & $0,036 \pm 0,121$ & $0,029 \pm 0,072$ & \\
\hline
\end{tabular}

Keterangan : superskrip berbeda pada baris yang sama menunjukan perbedaan yang tidak nyata $(\mathrm{P}>0.05) ; \mathrm{Sd}=$ Standar deviasi.

- 0,038 mm. Hasil penelitian ini lebih tinggi dibandingkan yang dilaporkan oleh Riawan et al. (2017), dimana indeks putih telur yang direndam menggunakan larutan daun kelor memberikan hasil 0,019 mm 0,029 mm. Hasil analisis ragam menunjukkan bahwa interaksi antara konsentrasi dan lama perendaman daun jambu biji tidak berpengaruh nyata $(\mathrm{P}>0,05)$ terhadap kualitas indeks putih telur.

Rataan konsentrasi larutan daun jambu biji tidak berpengaruh nyata $(\mathrm{P}>0,05)$ terhadap indeks putih telur. Hal ini menunjukkan bahwa konsentrasi larutan daun jambu biji sampai $12 \%$ memberikan nilai yang sama antar perlakuan. Bahan penyamak (tanin) yang terkandung didalam daun jambu biji yang menutup pori-pori kerabang telur sehingga gas $\mathrm{CO}_{2}$ dapat dihambat keluar. Tanin yang bereaksi dengan protein yang terdapat pada permukaan kerabang telur dan membentuk lapisan yang bersifat impermeable terhadap gas.
Rataan lama perendaman daun jambu biji tidak berpengaruh nyata $(\mathrm{P}>0,05)$ terhadap indeks putih telur. Lama perendaman telur menggunakan larutan daun jambu biji memberikan nilai indeks putih telur yang paling tinggi pada lama perendaman 18 jam $(0,036 \mathrm{~mm})$. Penyimpanan telur selama 30 hari pada penelitian ini menunjukkan indeks putih telur menurun. Standar Indeks putih telur berkisar antara 0,134-0,175 (BSN, 2008).

Indeks putih telur menunjukkan kecenderundungan bahwa semakin lama perendaman nilai indeks putih telur mengalami penurunan. Hal ini disebabkan karena putih telur mengalami pengenceran yang disebabkan oleh mikroorganisme. Mikroorganisme mendegradasi sebagian senyawa pada telur terutama pada putih telur sehingga menjadi encer dan mempercepat proses penguapan air dan gas $\mathrm{CO}_{2}, \mathrm{NH}_{2}, \mathrm{~N}_{2}$ dan $\mathrm{H}_{2} \mathrm{~S}$ (Riawan et al., 2017). Indeks putih telur juga dipengaruhi oleh lama penyimpanan, peningkatan $\mathrm{PH}$ akbiat penguapan $\mathrm{CO} 2$ dan kerusakan serabut ovomucin. 
Tabel 3. Rataan Indeks Kuning Telur

\begin{tabular}{cccccc}
\hline \multirow{2}{*}{$\begin{array}{c}\text { Konsentrasi } \\
\text { Larutan } \\
\text { Daun Jambu } \\
\text { Biji (\%) }\end{array}$} & 6 & 12 & 18 & 24 & Lama Perendaman (Jam) \\
\cline { 2 - 5 } & \multicolumn{5}{c}{$\begin{array}{c}\text { Rataan } \\
(\mathrm{mm})\end{array}$} \\
\hline 3 & $0,200 \pm 0,024$ & $0,140 \pm 0,029$ & $0,162 \pm 0,032$ & $0,157 \pm 0,021$ & $0,165 \pm 0,033$ \\
6 & $0,162 \pm 0,046$ & $0,380 \pm 0,577$ & $0,195 \pm 0,062$ & $0,195 \pm 0,028$ & $0,233 \pm 0,271$ \\
9 & $0,127 \pm 0,040$ & $0,077 \pm 0,035$ & $0,185 \pm 0,046$ & $0,305 \pm 0,351$ & $0,174 \pm 0,182$ \\
12 & $0,122 \pm 0,049$ & $0,147 \pm 0,070$ & $0,165 \pm 0,022$ & $0,157 \pm 0,050$ & $0,148 \pm 0,043$ \\
\hline Rataan & $0,153 \pm 0,059$ & $0,196 \pm 0,282$ & $0,187 \pm 0,041$ & $0,203 \pm 0,179$ & \\
\hline
\end{tabular}

Keterangan : superskrip berbeda pada baris yang sama menunjukan perbedaan yang tidak nyata $(\mathrm{P}>0.05) ; \mathrm{Sd}=$ Standar deviasi.

\section{Indeks Kuning Telur}

Rataan indeks kuning telur (Tabel

3) yang menggunakan konsentrasi larutan daun jambu biji berkisar antara $0,148 \mathrm{~mm}-$ $0,233 \mathrm{~mm}$. Hasil penelitian ini lebih tinggi dibandingkan yang dilaporkan oleh Riawan et al. (2017), dimana indeks kuning telur yang direndam menggunakan larutan daun kelor memberikan hasil 0,141 mm - 0,179 $\mathrm{mm}$. Hasil analisis ragam menunjukkan bahwa interaksi antara konsentrasi dan lama perendaman daun jambu biji tidak berpengaruh nyata $(\mathrm{P}>0,05)$ terhadap kualitas indeks kuning telur.

Rataan konsentrasi larutan daun jambu biji tidak berpengaruh nyata $(\mathrm{P}>0,05)$ terhadap indeks putih telur. Hal ini menunjukkan bahwa konsentrasi larutan daun jambu biji sampai 12\% memberikan nilai yang sama antar perlakuan. Transfer air ke dalam kuning telur menyebabkan elastisitas membrane vitelin berkurang sehingga tinggi kuning telur menurun.
Rataan lama perendaman daun jambu biji tidak berpengaruh nyata $(\mathrm{P}>0,05)$ terhadap indeks putih telur. Perendaman telur menggunakan larutan daun jambu biji memberikan nilai indeks kuning telur yang paling tinggi pada lama perendaman 24 jam $(0,203 \mathrm{~mm})$. Hal ini menunjukkan bahwa semakin lama waktu perendaman maka nilai indeks kuning telur semakin meningkat atau tinggi. Hal ini disebabkan karena tanin dalam larutan daun jambu biji mengandung asam ursolat yang dapat mengwetkan telur dalam waktu yang cukup lama yaitu 1 bulan (Sukardi et al., 2007).

Hasil ini hampir sama dengan penelitian Agustin (2007) menunjukkan bahwa telur yang direndam dengan kulit kayu akasia memiliki indeks kuning telur 0,20 mm. Standar indeks kuning telur segar berkisar antara 0,33-0,52 mm (BSN, 2008). Kandungan tanin dalam larutan daun jambu biji tidak dapat menghambat laju atau proses transfer air dari putih ke kuning telur. Hal ini disebabkan tekanan osmosis 
kuning telur lebih besar dari pada putih telur, sehinga air dan putih telur berpindah menuju ke kuning telur. Perpindahan air secara terus menerus akan menyebabkan ukuran kuning telur menurun, sehingga kuning menjadih pipih dan kemudian pecah, perpindahan air tergantung pada kekentalan putih telur (Sumitra and Made, 2012).

\section{KESIMPULAN}

Konsentrasi $3 \%$ dan lama perendaman 6 jam memberikan hasil yang baik pada penurunan berat telur. Sementara untuk indeks putih telur dan indeks kuning telur menunjukkan hasil yang baik dengan konsentrasi $12 \%$ dan lama perendaman 24 jam.

\section{DAFTAR PUSTAKA}

Agustin. 2007. Pemanfaatan ekstrak kulit kayu akasia (Acacia Auriculiformis) sebagai bahan pengawet telur dan pengaruhnya terhadap kualitas dan daya simpan telur. Jurnal Teknologi Pertanian Vol.3 (2): 58-62.

Badan Standarisasi Nasional. 2008. SNI ISO 9001-2000 Sistem Manajemen Mutu Persyaratan Jakarta.

Fadlillah, R., J. Handajani dan T. Haniastuti. 2010. Ekstrak daun jambu mete konsentrasi $10 \%$ yang dikumurkan dapat menghambat pertumbuhan streptococcus mutans saliva. Dentika Dental Journal. Vol (15) :135-140.

Hintono, A. 1997. Kualitas telur yang disimpan dalam kemasan atmosfer termodifikasi. Jurnal Sainteks. Vol. $4(3): 45-51$.

Kamila, Fasyah and Sa'adah. 2010. Faksinasi dan identifikasi senyawa tanin pada daun belimbing wuluh (Averrhoa bllimbi), Jurnal Kimia, Vol 4(2) : 193-200.

Koswara, S. 2009. Teknologi Pengolahan Telur (Teori dan Praktek). eBookPangan.com.

Kusriningrum. 2010. Perancangan Percobaan. Airlangga University Press. Surabaya.

Mulyadi, M. 2010. Kualitas Fisik Telur Ayam Ras Dan Telur Itik Yang Diawetkan Dengan Ekstrak daun Jambu Biji (Psidium guajava Linn) Dan Daun Jati (Tectona grandis) Pada Lama Penyimpanan Yang Berbeda. Skripsi. Universitas Islam Negeri Sultan Syarif Kasim Riau, Pekanbaru.

Riawan, Riyanti and K. Nova. 2017. Pengaruh perendaman telur menggunakan larutan daun kelor terhadap kualitas internal telur ayam ras. Jurnal Ilmiah Peternakan Vol. 59(1): 1-7.

Sukardi, A. R., Mulyarto and W. Safera. 2007. Optimasi waktu ekstraksi terhadap kandungan tanin pada bubuk ekstrak daun jambu biji serta biaya produksinya. J. Teknologi Pertanian Vol. 2(8): 88-94.

Sumitra, P. M. S and S. Made. 2012. Pengetahuan pedagang tradisional dalam penanganan telur ayam. Indonesia Medicus Veterinus. Jurnal Vol. 1(5): 657-673. 